ANNA S. CZYŻ* - WARSZAWA

\title{
Z BIBLIOTEKI PROBOSZCZA ANTOKOLSKIEGO KS. BENEDYKTA SZAMOTULSKIEGO
}

Postać ks. Benedykta Szamotulskiego (vel Samotulskiego), kanonika regularnego laterańskiego związana jest nierozerwalnie z parafią świętych Piotra i Pawła na wileńskim Antokolu. Był on piątym z kolei proboszczem i prepozytem tamtejszej wspólnoty, a jego niemal trzydziestoletnie rządy przypadły na bardzo ważny okres wznoszenia murowanej świątyni oraz rozpoczęcia prac przy budowie klasztoru kanoników regularnych laterańskich.

Do stolicy Wielkiego Księstwa Litewskiego zakonników z krakowskiego Kazimierza sprowadził w 1625 roku biskup wileński Eustachy Wołłowicz, przyznając im drewnianą świątynię parafialną na Antokolu pod Wilnem. Kanonicy regularni laterańscy nękani po śmierci hierarchy licznymi problemami, zostali oficjalnie wprowadzeni do kościoła św. Piotra dopiero 30 listopada 1638 roku. Ówczesny biskup Abraham Woyna potwierdził 22 czerwca 1639 roku nadanie konwentowi placu z domem i ogrodem, a także zarząd parafią ${ }^{1}$ oraz szpitalami ze wszystkimi własnościami. Jednocześnie parafii antokolskiej nadano drugiego patrona - św. Pawłaํ. Rozwój placówki kanoników regularnych laterańskich został przerwany w 1655 roku, kiedy Wilno zajęły wojska moskiewskie. Drewniane zabudowania

* Anna S. Czyż - dr historii sztuki, adiunkt w Katedrze Plastyki Nowożytnej, Instytut Historii Sztuki, Uniwersytet Kardynała Stefana Wyszyńskiego w Warszawie.

${ }^{1}$ Parafia św. Piotra obejmowała duży obszar. W jej skład wchodził nie tylko Antokol, ale również majątki Wirszupy, Kojrany oraz Rakanciszki z wsiami, Werki z folwarkami, dalej Antowil z przedmieściami Zawilja i Śnipiszki. Vilniaus Arkivyskupijos Kurija Archyvas (dalej VAKA), sygn. f. 1, ap. 5, b. 8, Liber Canonic[orum] Regul[arium] Conventus Viln[ensis] in Antocollo ad Ecclesiam S. Petri [...] Benedicto Samotulski praeposito conscriptus, [od 1668 roku], k. 21v, .

${ }^{2}$ Liber Canonicorum Regularium, k. 3v, 19-22v; Schema de Canonicis Regularibus Lateranensibus Congregationis Cracoviensis, w: Joannes de Nigra Valle Ord. Praemonstrat. Canonicorum regularium genealogiam amplitatus hui publicae reostensus per Aquilinum Michael Gorczyński..., Cracoviae 1707, s. 100; 64; A. S. Czyż, Kościót świętych Piotra i Pawła na Antokolu w Wilnie, Wrocław-Warszawa-Kraków 2008, s. 18-21; K. Łatak, Kongregacja krakowska kanoników laterańskich na przestrzeni dziejów, Kraków 2002, s. 123. 
klasztoru i kościoła zostały wówczas spalone. Gdy sytuacja nieco się uspokoiła władze zgromadzenia 8 czerwca 1658 roku powierzyły probostwo wileńskie ks. Benedyktowi Szamotulskiemu. Do stolicy Wielkiego Księstwa Litewskiego przybył on 6 lipca i natychmiast przystąpił do energicznych działań związanych z odbudową drewnianego kościoła oraz zakupem kamienicy na Antokolu, którą przystosowano na potrzeby klasztoru ${ }^{3}$. Regularne życie zakonne i duszpasterstwo kanonicy regularni laterańscy prowadzili w Wilnie od $1661 \mathrm{roku}^{4}$. W 1668 roku Michał Kazimierz Pac (1624-1682), hetman wielki litewski i przyszły wojewoda wileński (1669) ufundował dla nich murowany kościół pw. śś. Piotra i Pawła Z jego inicjatywy dziewięć lat później wmurowano kamień węgielny pod budowę klasztoru ${ }^{6}$. Osobą odpowiedzialną za obie realizacje, w tym za kontakty z architektami i dekoratorami z Włoch, był ks. Benedykt Szamotluski. Był on także współtwórcą programu ideowego kościoła antokolskiego, w którym czytelne są wątki odnoszące się do zgromadzenia kanoników regularnych laterańskich?

Mimo ogromnego znaczenia dla wspólnoty wileńskiej i dziejów kanoników regularnych laterańskich na terenie Wielkiego Księstwa Litewskiego o ks. Benedykcie Adamie Szamotulskim wiemy stosunkowo niewiele. Urodził się w 1620 roku w Lublinie, w rodzinie Anny i Macieja. Do zakonu wstąpił w kwietniu 1640 roku w Krakowie. W lutym 1641 roku złożył profesję. Sześć lat później 16 marca otrzymał święcenia kapłańskie. Od 1648 roku związany był z klasztorem w Kurozwękach, a następnie w Kraśniku (1650-1653) i Suchej Beskidzkiej (16531654). Z zachowanej korespondencji z czasów wileńskich ${ }^{8}$ oraz z prowadzonej przez niego kroniki klasztoru antokolskiego (Liber Canonicorum Regularium) wyłania się obraz troskliwego gospodarza powierzonego mu miejsca. Wybór ks. Szamotulskiego na proboszcza nie mógł być przypadkowy. Został nim w dramatycznym momencie wychodzenia Wilna wraz z całym Wielkim Księstwem Litewskim z ogromnych zniszczeń wojennych. Postawiono przed nim zadania odnowy życia zakonnego, odbudowy kościoła i klasztoru, a także rekonstrukcji majątku pozwalającego na funkcjonowanie placówki ${ }^{9}$. Nie do przecenienia jest jego rola w pozyskaniu dla zakonu możnego i wpływowego fundatora - Michała Kazimierza Paca. Zalety ks. Benedykta Szamotulskiego, którego określono w nekrologu

${ }^{3}$ Liber Canonicorum Regularium, k. 4-4v.

${ }^{4}$ Łatak, Kongregacja krakowska kanoników, s. 124.

${ }^{5}$ Liber Canonicorum Regularium, k. 2, 4v, 22.

${ }^{6}$ Tamże, k. 11v, 22v; Łatak, Kongregacja krakowska kanoników, s. 126.

${ }^{7} \mathrm{Na}$ temat budowy i dekoracji kościoła zob. Czyż, Kościót świętych Piotra i Pawła na Antokolu.

${ }^{8}$ Zbiór korespondencji ks. Benedykta Szamotulskiego jest obecnie rozproszony i przechowywany w takich wileńskich instytucjach jak VAKA, Vilniaus Universiteto Biblioteka (dalej VUB), oraz Lietuvos Mokslų Akademijos Biblioteka.

${ }^{9} \mathrm{O}$ tym, że z powierzonych mu zadań wywiązał się znakomicie świadczy wpis w nekrologu klasztoru krakowskiego: „Ibique multis annis existens multa bona fecie illi loco tamquam alter fundator, nam post devastationem Conventus per Moschos ipse proprio sumptu ex patrimonio suo extruxit." Archiwum Klasztoru Bożego Ciała, Memoriale fratrum, s. 124 (cytat za K. Łatak, Ksiadz Stefan Ranatowicz CRL (1617-1694). Barokowy kronikarz i pisarz klasztorny, Kraków 2010, s. 143, przyp. 79 .). 
klasztoru krakowskiego jako „vir multae patientiae, innumerosarum laborum”, dostrzegali jego przełożeni, wyznaczając go m.in. na wizytatora klasztorów litewskich w 1676 roku. Po rezygnacji z urzędu proboszcza antokolskiego w 1685 roku, jeszcze tego samego roku 5 lipca wyznaczono go na prepozyta w Kraśniku, z którym to klasztorem był związany wcześniej, pełniąc zapewne funkcję kaznodziei, i gdzie zmarł nagle 16 marca 1686 roku w wieku 66 lat $^{10}$.

Ks. Benedykta Szamotulskiego znamy także jako autora dwóch drukowanych kazań ${ }^{11}$. Pierwsze z nich - epicedium Mariny Węglińskiej (zm. 1651) zostało oparte na koncepcie rozwijanym wokół czterech rzek: Gangesu, Tygrysu, Nilu i Eufratu, które były wówczas uważane za najdłuższe rzeki świata. Jednocześnie wiązano z nimi symbolikę eschatologiczną opierając się na Biblii i, jak pisał proboszcz antokolski, wypływając z czterech różnych stron świata „w jedno miejsce się schodząc czynią rzekę żywota wiecznego, w której Duch ludzki omyty skrzydeł nieśmiertelnych nabywszy w niebieskie wybija się krasie"12. Drugi utwór autorstwa proboszcza antokolskiego to kazanie na temat imienia Maryi, wygłoszone w katedrze wileńskiej 13 września 1678 roku. Zostało ono dedykowane sufraganowi białoruskiemu biskupstwa wileńskiego Mikołajowi Słupskiemu ${ }^{13}$. Był on współinicjatorem i pierwszym prowizorem Arcybractwa Imienia Maryi przy katedrze wileńskiej, które uroczyście wprowadzono kilka lat wcześniej (8 III $1671)^{14}$.

Fakt głoszenia przez ks. Benedykta Szamotulskiego kazań, którym przypisywano w środowisku kanoników regularnych laterańskich wartość nadrzędną, wymagającą zarówno kwalifikacji duchowych jak i intelektualnych, świadczy że odebrał on staranne wykształcenie uniwersyteckie ${ }^{15}$. Wiadomo, że w zgroma-

${ }^{10}$ Liber Canonicorum Regularium, k. 155; B. Szamotulski, Rzeka żywota wiecznego [...] na pogrzebie [...] Mariny z Rzeczyce Węglińskiej w kościele kraśnickim ..., Lublin 1651, k. 1, 2; Łatak, Kongregacja krakowska kanoników, s. 92, 111; Łatak, Ksiadz Stefan Ranatowicz, s. 83, 101, 143.

${ }^{11}$ K. Estreicher, Bibliografia polska, t. 30, cz. 3 19, Kraków 1934, s. 193-194.

${ }^{12}$ Szamotulski, Rzeka żywota wiecznego, k. 3. Zob. L. Ryken, J. C. Wilhoit, T. Longman III, Stownik symboliki biblijnej. Obrazy symbole, motywy, metafory, figury stylistyczne i gatunki literackie w Piśmie Świętym, Warszawa 1998, s. 886-887.

${ }^{13}$ Testament Panny Przenajświętszej z woli Boga w Trójcy Jedynego synom i nabożnym stugom [...] legowany [...] do exekuciey [...] Mikołajowi Stupskiemu biskupowi [...] podany, [Wilno 1678].

${ }^{14}$ Wśród inicjatorów powołania arcybractwa maryjnego był także bp. Aleksander Sapieha oraz Michał Kazimierz Pac, a także jego krewny Mikołaj Stefan, od czerwca 1671 roku biskup nominat wileński. B. Kumor, Stupski Mikołaj h. Leszczyc, w: Polski Stownik Biograficzny, t. 39, WarszawaKraków 1999-2000, s. 130-131; A. Rachuba, Pac Mikołaj Stefan h. Gozdawa, w: Polski Stownik Biograficzny, t. 24, Wrocław-Warszawa-Kraków-Gdańsk 1979, s. 740. Zob. także hasło Księga wpisów Arcybractwa Imienia Maryi, w: Skarbiec katedry wileńskiej. Zamek Królewski w Warszawie 2 lipca - 28 września 2008. Zamek Królewski na Wawelu 15 października - 15 stycznia 2009, red. D. Nowacki, A. Saratowicz-Dudyńska, Warszawa 2008, s. 160-161.

${ }^{15}$ K. Latak, Kaznodziejstwo i spowiednictwo w kościele Bożego Ciała w XV wieku, w: Święty Stanistaw Kaźmierczyk CRL (1433-1489). Postać. Środowisko. Kultura. Dziedzictwo, red. K. Łatak, Kraków 2010, s. 293. 
dzeniu uchodził za znawcę prawa ${ }^{16}$. Podstawą dla wiedzy prawniczej i umiejętności głoszenia kazań była pogłębiona nauka, w tym teologiczna i filozoficzna oraz książka traktowana jako przepustka do życia apostolskiego. Zgromadzenie oparte na regule św. Augustyna, którego członkiem był ks. Benedykt Szamotulski, łączyło kontemplację z pracą duszpasterską. Zgodnie z wytycznymi biskupa z Hippony ważne miejsce w życiu wspólnot kanonickich zajmowała biblioteka ${ }^{17}$. $\mathrm{O}$ znaczeniu książki w klasztorach kanonickich nie zapominali kolejni reformatorzy zakonni, a papież Benedykt XI w konstytucji Ad decorem Ecclesiae sponsae suae nakazał kanonikom stałą troskę o biblioteki. Wagę nauki, postrzeganej na równi z modlitwą i dobrym działaniem, podkreślał w swoich rozważaniach Piotr Clareta z Rudnic (ok. 1383 - po 1406). Jego traktat wyrastający z tradycji devotio moderna nie stracił na popularności w XVII w., o czym przekonuje wydanie

${ }^{16}$ I. Pietrzkiewicz, Biblioteki kanoników regularnych laterańskich na ziemiach Wielkiego Księstwa Litewskiego - zarys problematyki badawczej, w: Przemijanie i trwanie. Kanonicy regularni laterańscy $w$ dawnej $i$ wspótczesnej Polsce. Materiaty z międzynarodowej konferencji zorganizowanej z okazji 600-lecia fundacji opactwa Bożego Ciała w Krakowie, red. K. Łatak, I. Makarczyk, Kraków 2008, s. 424.

${ }^{17}$ Mimo prowadzonych od lat studiów nad bibliotekami i książką w życiu kanoników regularnych laterańskich temat ten kryje nadal wiele nierozwiązanych kwestii. Do najważniejszych publikacji podejmujących to zagadnienie należą: A. Chlewicka, Dary dla bibliotek kanoników regularnych na ziemiach polskich, w: Przemijanie i trwanie, s. 75-95; J. Kiwiliszo, Średniowieczna biblioteka klasztoru kanoników regularnych w Czerwińsku. Analiza zawartości treściowej, „Rocznik Biblioteki Narodowej”, 23-24 (1987-1988 [1991]) s. 229-254; I. Pietrzkieiwicz, Książka u kanoników regularnych laterańskich w świetle spisu Elenchus locorum libris ex Bibliotheca Cracoviensi Corporis Christi z 1811 roku, w: Kraków-Lwów. Książki, czasopisma, biblioteki XIX i XX wieku, red. J. Jarowiecki, t. 4, Kraków 1999, s. 187-194; I. Pietrzkieiwicz, Księgozbiory konwentów i szkół kanoników regularnych laterańskich na ziemiach Wielkiego Księstwa Litewskiego, „Nasza Przeszłość”, 92 (1999) s. 485-497; I. Pietrzkieiwicz, Biblioteka kanoników regularnych w Krakowie w XV i XVI wieku, Kraków 2003, s. 421-431; A. Świerk, Średniowieczna biblioteka klasztoru kanoników regularnych św. Augustyna w Żaganiu, Wrocław 1965; A. Świerk, Śląskie biblioteki do początku XVI wieku, w: Studia z dziejów kultury i teologii, Wrocław 1968, s. 79-89; Z. Włodek, Inventaire des manuscrits medievaux latins, philosophes et theologiques de la bibliotheque de chanoines reguliers de Cracoviae, „Mediaevalia Philosophica Polonorum”, 16 (1970) s. 87-102; H. D. Wojtyska, Czytelnictwo i biblioteki u kanoników regularnych laterańskich kongregacji Bożego Ciała (XV-XVIII w.), w: Kanonicy regularni laterańscy w Polsce. Studia z dziejów kongregacji krakowskiej XV-XIX wieku, red. Z. Jakubowski, Kraków 1975, s. 53-72; H. D. Wojtyska, Nauka i nauczanie u kanoników regularnych (na przyktadzie kongregacji Bożego Ciała), w: Dzieje teologii katolickiej w Polsce, red. M. Rechowicz, t. 2, cz. 2, Lublin 1975, s. 455-477; L. Zalewski, Biblioteka Ks. Ks. kanoników regularnych laterańskich w Kraśniku, „Wiadomości Diecezji Lubelskiej”, 4 (1922) z. 1 s. 34-46; z. 2, s. 79-87; L. Zalewski, Biblioteka Seminarium Duchownego w Lublinie i biblioteki klasztorne w diecezji lubelskiej i podlaskiej, Warszawa 1926; E. Zielińska, Biblioteka klasztoru kanoników regularnych w Kraśniku w drugiej połowie XV wieku, w: Klasztor w kulturze średniowiecznej Polski, red. A. Pobóg-Lenartowicz, M. Derwich, Opole-Wrocław 1995, s. 105-112; E. Zielińska, Kontakty konwentu kanoników regularnych $w$ Kraśniku z jego otoczeniem społecznym $w$ drugiej połowie XV i XVI wieku w świetle ksiegozbioru klasztornego, w: Klasztor w społeczeństwie średniowiecznym i nowożytnym, s. 233-239; E. Zielińska, Kultura intelektualna kanoników regularnych z klasztoru w Kraśniku w latach 1469-1536, Lublin 2002. 
drukiem rękopisu wraz z regułą św. Augustyna w 1618 roku przez ówczesnego prepozyta kongregacji krakowskiej Marcina Kłoczyńskiego (zm. 1644). Szczegółowe przepisy dotyczące bibliotek kanoników regularnych laterańskich zawierały przede wszystkim konstytucje zakonne. Omawiano w nich funkcjonowanie zbiorów, ale podkreślono także wagę indywidualnej lektury, która przynosiła nie tylko pożytek zakonnikowi, ale poprzez efektywniejszą pracę duszpasterską była dobrem całego zgromadzenia. W zapisach regulujących życie klasztoru Bożego Ciała w Krakowie, sporządzonych pod koniec XVI w. przez kardynała Jerzego Radziwiłła, znalazło się stwierdzenie, że w celi zakonnika prócz łóżka i ubrania może znaleźć się jedynie książka. Przełom wieków XVI i XVII to także moment, w którym kanonicy regularni laterańscy zwrócili uwagę nie tylko na wspólną bibliotekę, ale i na gromadzenie własnych zbiorów. Choć nadal podkreślano ideę wspólnotowości, wyjątek własności czyniono dla książek przechowywanych w celach. Książki posiadali u kanoników nawet klerycy, a o ich właścicielach świadczą wpisy własnościowe. Warto także przypomnieć, że „lectio librorum” zostało przez kapitułę generalną w 1685 roku określone, jako pierwsze pozachórowe zajęcie kanonika, przed pisaniem kazań i pracami ręcznymi. Prywatne zbiory książek były zwykle po śmierci zakonnika włączane do biblioteki klasztornej. Mogły się tam znaleźć także wcześniej, na zasadzie daru. Część z nich zakonnik przekazywał także w momencie, gdy opuszczał placówkę ${ }^{18}$.

Prywatny księgozbiór miał także ks. Benedykt Szamotulski, o czym świadczą odnalezione autografy na kilku woluminach przechowywanych w wileńskich bibliotekach i archiwach ${ }^{19}$. Najstarszą pozycją $\mathrm{z}$ autografem proboszcza antokolskiego jest jedno z wydań Emblmatów Andrei Alciatiego (1492-1550). Wpis własnościowy znajduje się na odwrocie frontispisu: „Bendictus Szamotulsky Canonicus / Regularis / Pro Conventum Vilnensis in Antocollis / Canonicorum Regularium Lateranens". Nota bene jest to jedyny zachowany fragment z tej książki, przechowywany obecnie w Vilniaus Arkivyskupijos Kurija Archyvas ${ }^{20}$. Nie można wykluczyć, biorąc pod uwagę dedykacyjny charakter wpisu, że właściwy znak własnościowy ks. Benedykt Szamotulski umieścił na niezachowanej karcie tytułowej. Na podstawie porównań różnych edycji poczytnych w XVII w. Emblematów można stwierdzić, że w posiadaniu ks. Benedykta Szamotulskiego był egzemplarz z 1621 roku Andreae Alciati Emblemata cum commentariis Claudii

${ }^{18}$ Chlewińska, Dary dla bibliotek, s. 77; Łatak, Kongregacja krakowska kanoników, s. 36, 68-71, 80-82; Pietrzkiewicz, Biblioteka kanoników regularnych, s. 36-42, 44-47, 50-51, 63, 79-83; Wojtyska, Czytelnictwo i biblioteki, s. 53-72; Wojtyska, Nauka i nauczanie, s. 455-477.

${ }^{19}$ Informację o własnym księgozbiorze ks. Benedykta Szamotulskiego podano na marginesie rozważań w następujących opracowaniach: E. Laucevičius, XV-XVIII a. knygu ịrišimai Lietuvos bibliotekose, Vilnius 1976, s. 56, przyp. 3 oraz A. Pacevičius, Kanonickie marginalia i proweniencje $w$ zbiorach bibliotecznych Litwy, w: Przemijanie i trwanie, s. 407, przyp. 33. Nie przytoczono tam jednak ani tytułów książek ani brzmienia wpisów własnościowych. Zob. także przypis 21.

${ }^{20}$ VAKA, sygn. f. 1 ap. 7 b. 3 . W archiwum tym jest ponadto przechowywanych kilka destruktów - każdy z nich bez okładzin i strony tytułowej. Są to m.in. druki związane z antokolskim Bractwem Pięciu Ran Pana Jezusa, zbiór kazań i dzieło dotyczące historii starożytnej. Wszystkie wydane zostały w języku polskim. 
Minois I. C. Francisci Sanctii Brocensis et Notis Laurentii Pignorii Patavini... wydany przez Lorenza Pasquato w Padwie.

Kolejny wpis własnościowy („Benedictus / Szamotulsky / Can. Reg.” ${ }^{21}$ ) proboszcz antokolski złożył na stronie tytułowej książki Vox turturis seu de Florenti usque ad nostra tempora SS. Benedicti, Dominici, Francisci... autorstwa Dominica Gravina (ok. 1573-1643), którą w 1638 roku wydał w Kolonii Henricus Krafft22. (il. 1) Na stronie tytułowej znajdują się także dwie inne atrybucje. Jedna z nich jest nieczytelna - kilkakrotnie przekreślona i można jedynie domyślać się, że jest to wpis własnościowy biblioteki klasztoru Bożego Ciała (odczyt niepewny). Drugi wpis własnościowy brzmi następująco: „Ex libris Stephani Kl[anar]ski”, a o osobie tej nie da się nic - nawet w przybliżeniu powiedzieć. Omawiany egzemplarz jest również ciekawy ze względu na oprawę plakietową z jasnej skóry, z wyciśniętymi superekslibrysami. (il. 2) Na okładzinie górnej znajduje się herb Łodzia z lemmą FRUSTRA VIVIT QVI NEMINI PRODEST (wycisk przyciemniony), a na okładzinie dolnej dziewięciopolowy herb Wazów z orderem Złotego Runa (wycisk ślepy). (il. 3) Superekslibris z herbem z okładziny przedniej, ujęty zacytowaną wyżej lemmą, znany był w środowisku kanoników regularnych laterańskich od czasów prepozyta Stanisława Manickiego (zm. 1610), pieczętującego się właśnie herbem Łodzia. Takiemu supereksilibrysowi towarzyszyły zwykle inicjały z tytulaturą (S. M. P. G., w przypadku ks. Stanisława Manickiego) ${ }^{23}$. Liter brakuje w superekslibrysie na książce ks. Szamotulskiego, który ponadto nie pieczętował się Łodzią. Jeszcze ciekawszym jest fakt, że dolną okładzinę zdobi, wykonany w innej technice (wycisk ślepy) superekslibris z kartuszem z dziewięciopolową tarczą pod koroną zamkniętą, z herbami Polski, Litwy, Szwecji, Gotlandii i Wazów, otoczoną akantem przechodzącym w łańcuch z Orderem Złotego Runa. Bardzo zbliżony kształt do supereksilibrysu wileńskiego miały supereksilibrysy książek z biblioteki Zygmunta III ${ }^{24}$. Jednak data wydania dzieła - 1638 roku, jednoznacznie wskazuje, że nie mógł być on jej właścicielem. Pierwszym jej posiadaczem była zapewne osoba pieczętująca się herbem Łodzia, która przekazała książkę Władysławowi IV. Wiemy, że książki nabyte przez niego w okresie panowania były oprawiane w skórę lub pergamin i posiadały złocone superekslibrysy herbowe. Obecnie znamy cztery różne oprawy książek Władysława IV i na żadnej z nich dziewięciopolowy herb nie został ujęty orderem Złotego Runa ${ }^{25}$. Do supereksilibrysu wileńskiego, zbliża się najbardziej ten z książki Statuła inclyti ac heroici ordinis equitum immaculatae Virginis autorstwa Jerzego Ossolińskiego

${ }^{21}$ Częściowo błędnie autograf ten odczytał Edmundas Laucevičius - „Benedictus Szamotulski (Cons.) Reg.” Laucevičius, XV-XVIII a. knygu ìrišimai, s. 56, przyp. 3.

22 VUB, sygn. III 418.

${ }^{23}$ Analogicznie skonstruowany był superekslibris prepozyta mstowskiego Andrzeja Strzembosza (zm. 1640), pieczętującego się herbem Jastrzębiec. K. Łatak, S. Nalbach, Ze studiów nad kultura umysłowa kanoników regularnych krakowskiej prepozytury Bożego Ciała wXV i w XVI wieku, Kraków 2009, s. 262-263.

${ }^{24}$ I. Komasa, Książka na dworach Wazów w Polsce, Wrocław 1994, s. 215-222.

${ }^{25}$ Tamże, s. 169, 222-223. Zob. także Laucevičius, XV-XVIII a. knygu irišimai, s. 56. 
(wyd. po 1634) ${ }^{26}$. Podstawową różnicą jest brak w krakowskim supereksilibrysie orderu Złotego Runa oraz inny kształt korony. Te ostatnie elementy zbliżają się natomiast do analogicznych motywów stosowanych w superekslibrysach Zygmunta III. Nie powinno to dziwić, bowiem charakter opraw Władysława IV zbliżał się do opraw wykonywanych na zamówienie Zygmunta III, co wskazuje że dla obu Wazów pracowali ci sami introligatorzy ${ }^{27}$.

Jak powiedziano wyżej ks. Benedykt Szamotulski nie był pierwszym właścicielem książki, o czym świadczą nie tylko superekslibrysy, ale i umiejscowienie jego podpisu - wciśniętego w puste pole po prawej stronie tytułu. Zakładając, że najpierw znalazła się ona w rękach osoby pieczętującej się herbem Łodzia, a następnie weszła w skład kolekcji Władysława IV, to kolejnym jej właścicielem mogła zostać biblioteka klasztoru Bożego Ciała ${ }^{28}$. Stamtąd zapewne do Wilna przywiózł ją ks. Benedykt Szamotulski. Niestety nie wiadomo, kiedy książka znalazła się w rękach Stefana Klanarskiego. O tym, że omawiane dzieło Dominica Gravina było ważne dla ks. Benedykta Szamotulskiego świadczą notatki uczynione przez niego na wyklejce górnej. Proboszcz antokolski wynotował z treści książki świętych, którzy byli kanonikami regularnymi laterańskimi. Owa lista sporządzona przez proboszcza antokolskiego liczy 32 osoby, z czego większość to papieże.

Kolejny wpis własnościowy znajduje się na frontyspisie książki Xenia et sermones problematicae cum paradoxis et baculo... autorstwa ks. Joannesa Brigeliusa z Eltville am Rhein, która została wydana w Moguncji w 1647 roku w drukarni Nicolausa Heylego i zawiera trzy rozprawy ${ }^{29}$. (il. 4) Na prawym marginesie frontispisu proboszcz napisał: „Pr Benedict Szamotuls Can Reg.” Skróty, które się tu pojawiły wynikają ze złego rozplanowania napisu, na który po prostu zabrakło miejsca. Na trzeciej karcie znajduje się kolejny wpis, dokonany tym razem inną ręką: „Pro Bibliotheca Convent ${ }_{9}$ Vil: / nensis Can Reg Latt. Congreg. Cracovien”. Po drugiej z kolei rozprawie Joannesa Brigeliusa Pars altera paradoxa seu casuae... znajdują się dwie puste karty. Na drugiej z nich umieszczony został wpis, którego także nie dokonał sam ks. Szamotulski: „Ex libris Probis Benedicti / Szamotulski Canonici Ragularis". Następna w kolejności jest rozprawa Pars tertia aestivalis. Topiarium croceis halantis... Na jej ostatniej stronie znajduje się mało czytelny wpis „Adm Rdê Dnê D[...] / Et Ant[...]e Observantie”. Omawiany egzemplarz także ma oprawę plakietową. Na górnej okładzinie widnieje wyciśnięty superekslibris z herbem Leliwa ujętym literami: N S / A A S / P Z, co należy uznać za znak własnościowy pierwszego właściciela książki.

Inny z autografów odnajdujemy na karcie tytułowej utworu Mateusza Dłuskiego Practica prudentiae politicae et militaris in 246 axiomata congesta..., który

${ }^{26}$ Egzemplarz z biblioteki Władysława IV znajduje się w Bibliotece Książąt Czartoryskich (sygn. saf. 33699 I). Komasa, Książka na dworach Wazów, s. 222, 226, 237.

${ }^{27}$ Tamże, s. 169.

${ }^{28}$ W bibliotece klasztoru Bożego Ciała w Krakowie znajduje się książki, które wcześniej tworzyły kolekcje królewskie. Są to m.in. książki z supereksilibrysem Zygmunta Augusta. Informacja od ks. prof. dr hab. Kazimierza Łataka.

${ }^{29}$ VUB, sygn. III 4184. 
wydała wileńska oficyna franciszkanów w 1670 roku $^{30}$. Charakterystycznym pismem, uczynionym jakby niewprawną ręką, właściciel książki zanotował: „Bendictus Szamotulsky / Canon Regular”. Niemal ten sam wpis proboszcz antokolski powtórzył na wklejce górnej: „Benedictus Samotulsky / Canonicus Regularis”31.

Ostatni autograf ks. Benedykta Szamotulskiego udało się rozpoznać w książce Vitis mystica. Viti verae, quae Christus est... autorstwa jezuity Christophora Brauna, wydanej w Kolonii w 1677 roku w drukarni Hermana Demena ${ }^{32}$. (il. 5) Widnieje on po dwóch stronach karty tytułowej, po lewej stronie: „Pro Conventu / Antocollen: Can: Regulari Latt.”, po prawej stronie: „Benedictus / Samotulsky / Canonicus / Regularius".

Niestety nie da się powiedzieć ile woluminów liczyła prywatna biblioteka ks. Szamotulskiego i kiedy weszła ona w skład książnicy klasztoru wileńskiego. Nie wiemy czy gromadzone przez proboszcza książki miały określony charakter, czy też był to raczej księgozbiór o charakterze przypadkowym. Wiadomo natomiast, że biblioteka klasztoru wileńskiego liczyła w 1705 roku 397 tomów, a w latach 20. XIX w. 2197 książek $^{33}$. Co najmniej pięć z nich pochodziło z prywatnego zbioru ks. Benedykta Szamotulskiego i zapewne stanowi to zaledwie ułamek jego kolekcji. Do książnicy klasztornej, przynajmniej w części, musiały one zostać przekazane w lipcu 1685 roku, kiedy to zakonnik przygotowywał się do wyjazdu z Wilna, przenosząc się do Kraśnika. Świadczą o tym dedykacyjne wpisy na większości wymienionych wyżej woluminach. Zapewne przed wyjazdem do porządkowania biblioteki ks. Benedykta Szamotulskiego został wydelegowany pomocnik, o czym świadczą dedykacyjne wpisy wykonane inną ręką (chodzi o Xenia et sermones problematicae cum paradoxis et baculo... oraz Vitis mystica. Viti verae, quae Christus est... $)^{34}$. Charakterystyczne, że książki wydane w drugiej połowie XVII w. zawierają jedynie autograf proboszcza antokolskiego. Te opublikowane w latach 30. i 40. XVII w. znajdowały się wcześniej w innych zbiorach ${ }^{35}$. W rękach ks. Benedykta Szamotulskiego mogły się znaleźć czy to poprzez zakup czy też poprzez dar, tym bardziej że wyznaczony na proboszcza kościoła pw. śś. Piotra i Pawła miał za zadanie zorganizowanie całej placówki, w tym biblioteki klasztornej, praktycznie od nowa.

${ }^{30}$ VUB, sygn. III 280. Estreicher, Bibliografia, t. 15, cz. III 4, Kraków 1897, s. 248.

${ }^{31}$ Napis jest w większości zasłonięty przez wklejkę „Виленская Публичная Библіотека”, poniżej znajduje się napis piórem „Ex 10 No / N 120”. Na grzbiecie okładziny znajduje się skrót tytułu, oraz nr 111, który zapewne odnosi się do biblioteki antokolskiej. Na karcie 2 w dolnej części umieszczono napis: „Pro Contu Vilnen. Can. Regul. Laterans“, który nie został wykonany przez ks. Benedykta Szamtulskiego.

${ }^{32}$ VUB, sygn. III 6188. W klocku tym znajduje się drugie dzieło Christopha Brauna Sanctuarium hoc est sermones panegyrici sanctorum omnium ... wydane tego samego roku i w tym samym miejscu (VUB, sygn. III 6189).

${ }^{33}$ Wojtyska, Nauka i nauczanie, s. 476; Pietrzkiewicz, Biblioteki kanoników regularnych, s. 427.

${ }^{34}$ Także prowadzona przez ks. Benedykta Szamotulskiego kronika klasztoru antokolskiego (Liber Canonicorum Regularium) była w części zapisywana przez inną osobę. Dotyczy to m.in. wpisywanych do niej dokumentów, czy prowadzenia spisu zakonników.

${ }^{35}$ Trudno powiedzieć coś więcej o Emblematach Alciatiego, ze względu na zachowaną jedną kartę z książki. 
Z całą pewnością wymieniona wyżej literatura religijna wchodząca w skład książnicy ks. Benedykta Szamotulskiego nie wyróżniała go spośród innych kanoników regularnych laterańskich. Nie dotyczy to także Emblematów Andrei Alciatiego, które dostarczały mówcom, w tym kaznodziejom, pomysłów na rozbudowane alegorie. Wiadomo także, że inne dzieło Andrei Alciatiego Libellus de ponderibus et mensuribus item Philippi Melanchtonis de eiusdem sententiae (wyd. Wenecja 1532) znajdowało się w bibliotece kazimierskiej ${ }^{36}$. Za oryginalne należy uznać posiadanie przez ks. Benedykta Szamotulskiego książki Mateusza Dłuskiego Practica prudentiae politicae et militaria... Można jednak założyć, że jednocześnie wpisywała się ona w dział politici, który wymienił w aktach wizytacji klasztoru, a więc i biblioteki antokolskiej ks. Marceli Włoszkiewicz (zm. $1728)^{37}$.

Wspomniane pięć książek łączy nie tylko osoba właściciela, ale także sposób ich wykorzystania i powiązania $\mathrm{z}$ fundatorem murowanego kościoła pw. śś. Piotra i Pawła na Antokolu - hetmanem wielkim litewskim i wojewodą wileńskim Michałem Kazimierzem Pacem. Practica prudentiae politicae et militaria... Mateusza Dłuskiego została dedykowana magnatowi, który sfinansował jej wydanie. Herb Gozdawa wieńczy dekorację panopliową, która ujmuje pole z tytułem na frontyspisie. Znak Paców powtórzono także na tarczy po lewej stronie. Wreszcie na karcie drugiej Practica prudentiae politicae et militaria ... znajduje się graficzny portret Michała Kazimierza Paca, oryginalny bowiem przedstawiono go konno, w zbroi, z buławą w dłoni i z tarczą ozdobioną herbową Gozdawąa $a^{38}$. Zarówno te dwie kompozycje graficzne jak i te z Vitis mystica... ukazujące różne sceny symboliczne i ilustrujące wydarzenia biblijne, czy też grafiki z Emblematów Alciatiego mogły stać się inspiracją dla ks. Benedykta Szamotulskiego przy kreowaniu wielowątkowego programu ikonograficznego kościoła pw. śś. Piotra i Pawła na Antokolu w Wilnie. Nie ulega bowiem wątpliwości, że stiukatorzy z Ticino - Giovanni Maria Galli (notowany 1677-1684) oraz Pietro Perti (1648-1714) wykształceni na najlepszych wzorcach sztuki włoskiej spotkali się z akceptacją i zrozumieniem zaproponowanych rozwiązań formalnych, w tym ornamentalnych (panoplia $\mathrm{z}$ herbem Gozdawa w prezbiterium świątyni antokolskiej) fundatora świątyni Michała Kazimierza Paca, jak i jej opiekuna ks. Benedykta Szamotulskiego. Ten ostatni stworzył dla nich podbudowę treściową opierając się m.in. na konceptach Alciatiego czy wskazując na świętych kanoników z Vox turturis seu

\footnotetext{
${ }^{36}$ Pietrzkiewicz, Biblioteka kanoników regularnych, s. 124.

${ }^{37}$ Ks. Marceli Włoszkiewicz w aktach wizytacji z lat 1692-1697 wymienił książki podzielone na grupy: concionatores, instructores, expositores, spirituales, theologi, canonistae, philosophi, oratores, historici, politici, poetae. Po kasacie klasztoru wileńskiego zbiór książek wszedł częściowo do tamtejszego seminarium diecezjalnego. Pozostałe książki przejął Kurator Wileńskiego Okręgu Szkolnego, przekazując je następnie Bibliotece Uniwersyteckiej, gdzie znajdują się do dziś. Wojtyska, Czytelnictwo i biblioteki, s. 65-66; Pietrzkiewicz, Biblioteka kanoników regularnych, s. 187; taż, Zarys dziejów biblioteki księży kanoników regularnych laterańskich w Krakowie, „Rocznik Naukowo-Dydaktyczny WSP w Krakowie. Prace Bibliotekoznawcze”, 9 (1998) z. 194, s. 26.

${ }^{38}$ Portret nieodnotowany wśród konnych portretów magnaterii polskiej i litewskiej, stanie się w przyszłości przedmiotem oddzielnego studium.
} 
de Florenti... ilustrując we wnętrzu kościoła antokolskiego genealogię zakonu (m.in. święci papieże związani z kanonikami regularnymi laterańskimi) ${ }^{39}$.

Zaprezentowane tu pięć książek, które były własnością ks. Benedykta Szamotulskiego $\mathrm{z}$ jednej strony poszerza naszą wiedzę o jednym $\mathrm{z}$ aktywniejszych kanoników regularnych laterańskich XVII w., a także przyczynia się do lepszego poznania prywatnych i wspólnotowych bibliotek zakonnych. Na szczególną uwagę zasługuje przy tym pozycja Vox turturis seu de Florenti usque ad nostra tempora SS. Benedicti, Dominici, Francisci..., ponieważ ks. Benedykt Szamotulski był jednym z jej właścicieli. Wśród nich była także osoba pieczętująca się herbem Łodzia, a nade wszystko Władysław IV, co do tej pory nie zostało odnotowane w literaturze polskiej dotyczącej księgozbiorów wazowskich. Nie można wykluczyć, że dalsze kwerendy prowadzone nie tylko w Wilnie, ale i w Polsce pozwolą odnaleźć kolejne książki z wpisami własnościowymi proboszcza antokolskiego ${ }^{40}$.

\title{
FROM THE LIBRARY OF THE PARISH PRIEST OF THE ANTAKALNIS, THE REV. BENEDYKT SZAMOTULSKI
}

\begin{abstract}
Summary
The article presents five books, which were in possession of the Rev. Benedykt Szamotulski (1620-1686), one of the most active Canons Regular of the Lateral in the seventeenth-century Republic of Poland, the parish priest of the St Peter and St Paul's Church in the Antakalnis in Vilnius.

These are the titles which were identified thanks to the ownership entries: Andreae Alciati Emblemata cum commentariis Claudii Minois I. C. Francisci Sanctii Brocensis et Notis Laurentii Pignorii Patavini... (published in Padua in 1621), Vox turturis seu de Florenti usque ad nostra tempora SS. Benedicti, Dominici, Francisci... (published in Cologne in 1638), Xenia et sermones problematicae cum paradoxis et baculo (published in Mainz in 1647), Practica prudentiae politicae et militaris in 246 axiomata congesta... (published in Vilnius in 1670) and Vitis mystica. Viti verae, quae Christus est... (published in Cologne in 1677). Although the mentioned books are typical examples of private libraries of Canons Regular of the Lateral, they were used by the Rev. Benedykt Szamotulski for designing the ideological program of the interior of the St Peter and St Paul's Church in the Antakalnis in Vilnius. A particularly valuable book in the Rev Szamotulski's library was Vox turturis seu de Florenti usque ad nostra tempora SS. Benedicti, Dominici, Francisci...,.. It was previously in possession of Władysław IV. The evidence of this ownership is superexlibris with the coat of arms of the House of Vasa with the Order of the Golden Fleece. So far, this book has not been mentioned in the literature on the book collections of the House of Vasa.
\end{abstract}

Translated by Aneta Kiper

${ }^{39}$ Zob. Czyż, Kościół świętych Piotra i Pawła; taż, Wątki kanonickie w dekoracji kościoła pw. śś. Piotra i Pawła na Antokolu w Wilnie, w: Przemijanie i trwanie, s. 97-119.

${ }^{40}$ Część księgozbioru ks. Benedykta Szamotulskiego znajduje się w klasztorze Bożego Ciała na krakowskim Kazimierzu. 


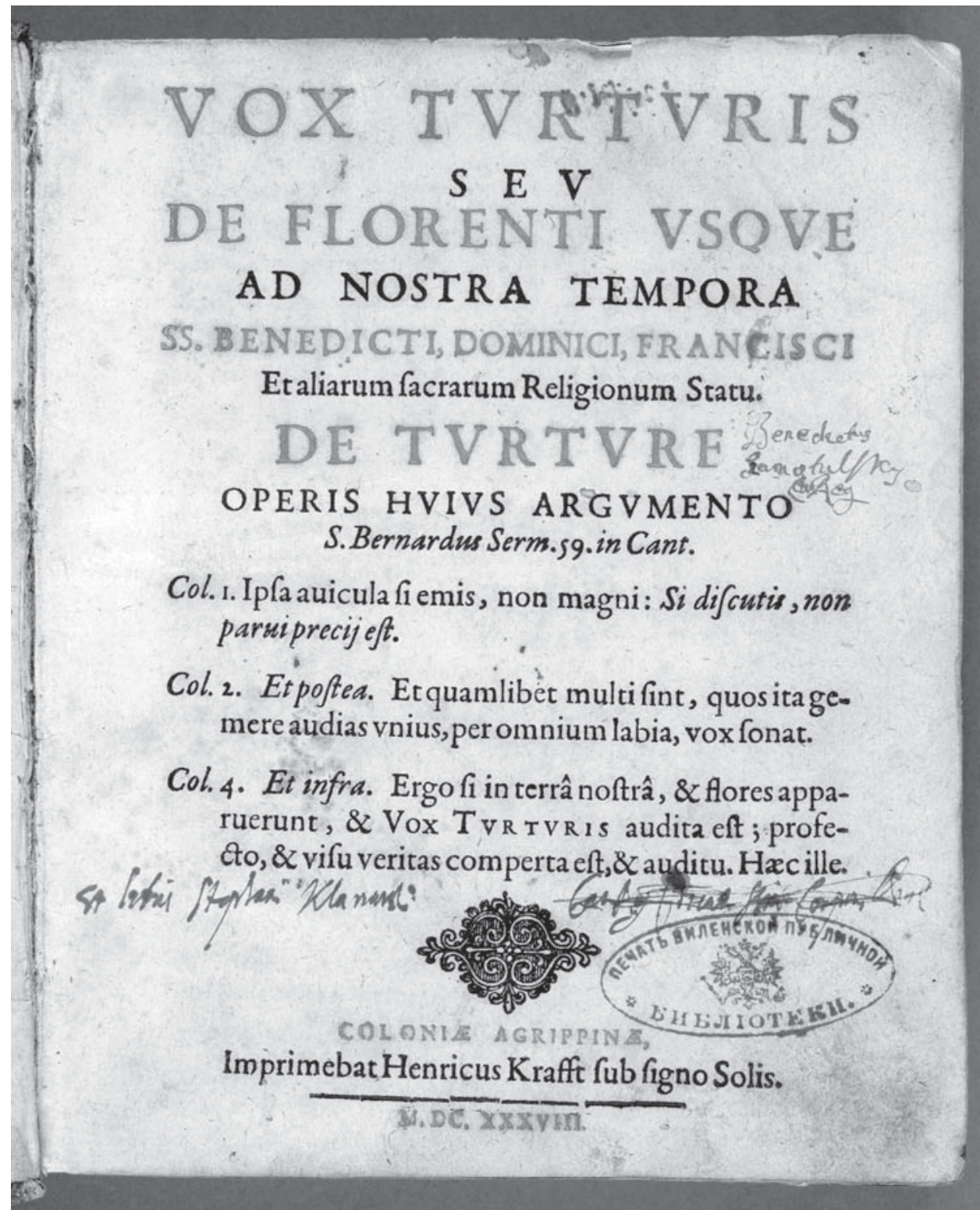

Strona tytułowa - Vox turturis seu de Florenti usque ad nostra tempora SS. Benedicti, Dominici, Francisci..., Kolonia 1638 


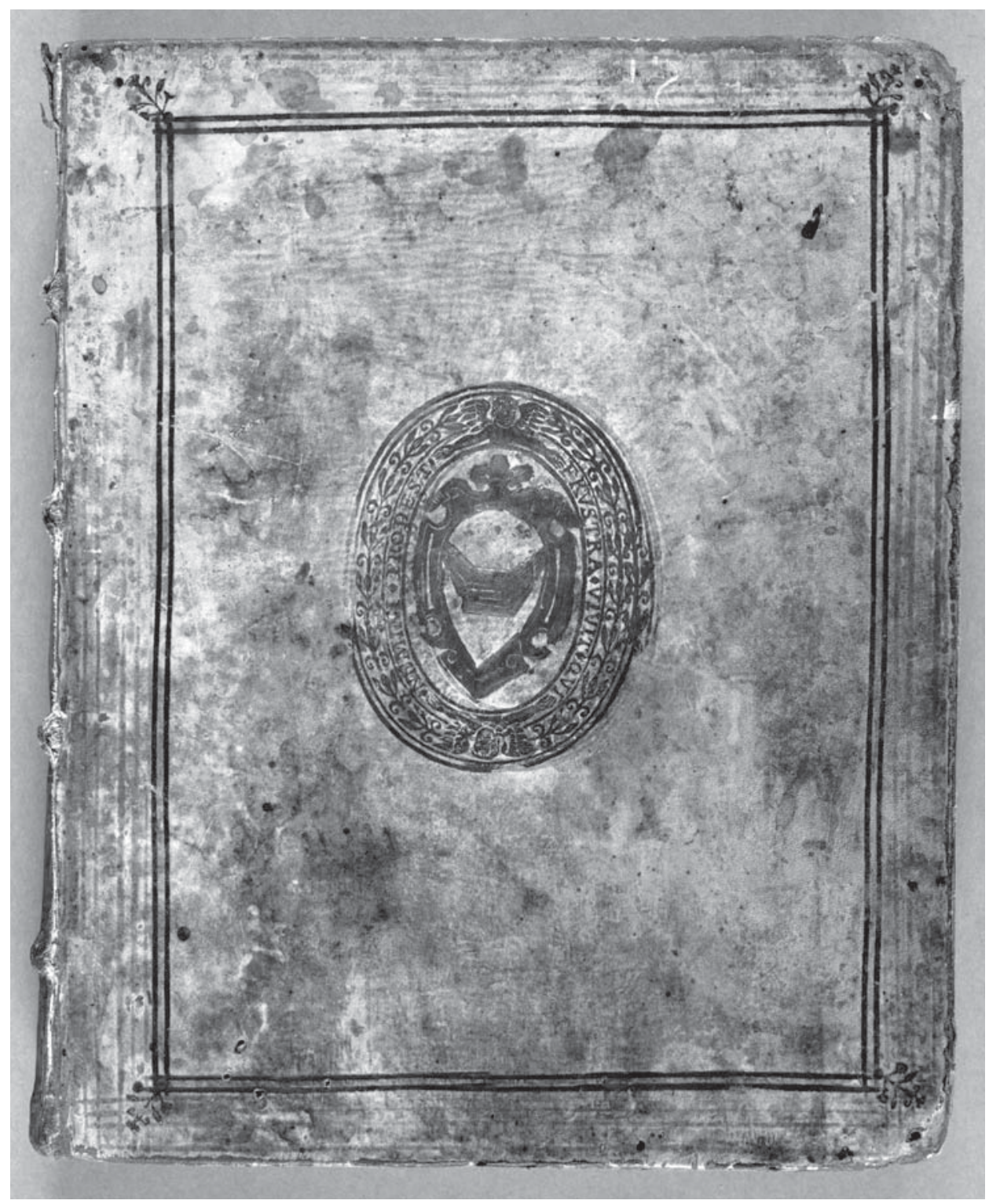

Superekslibris z herbem Łodzia okładziny górnej książki Vox turturis seu de Florenti usque ad nostra tempora SS. Benedicti, Dominici, Francisci... 


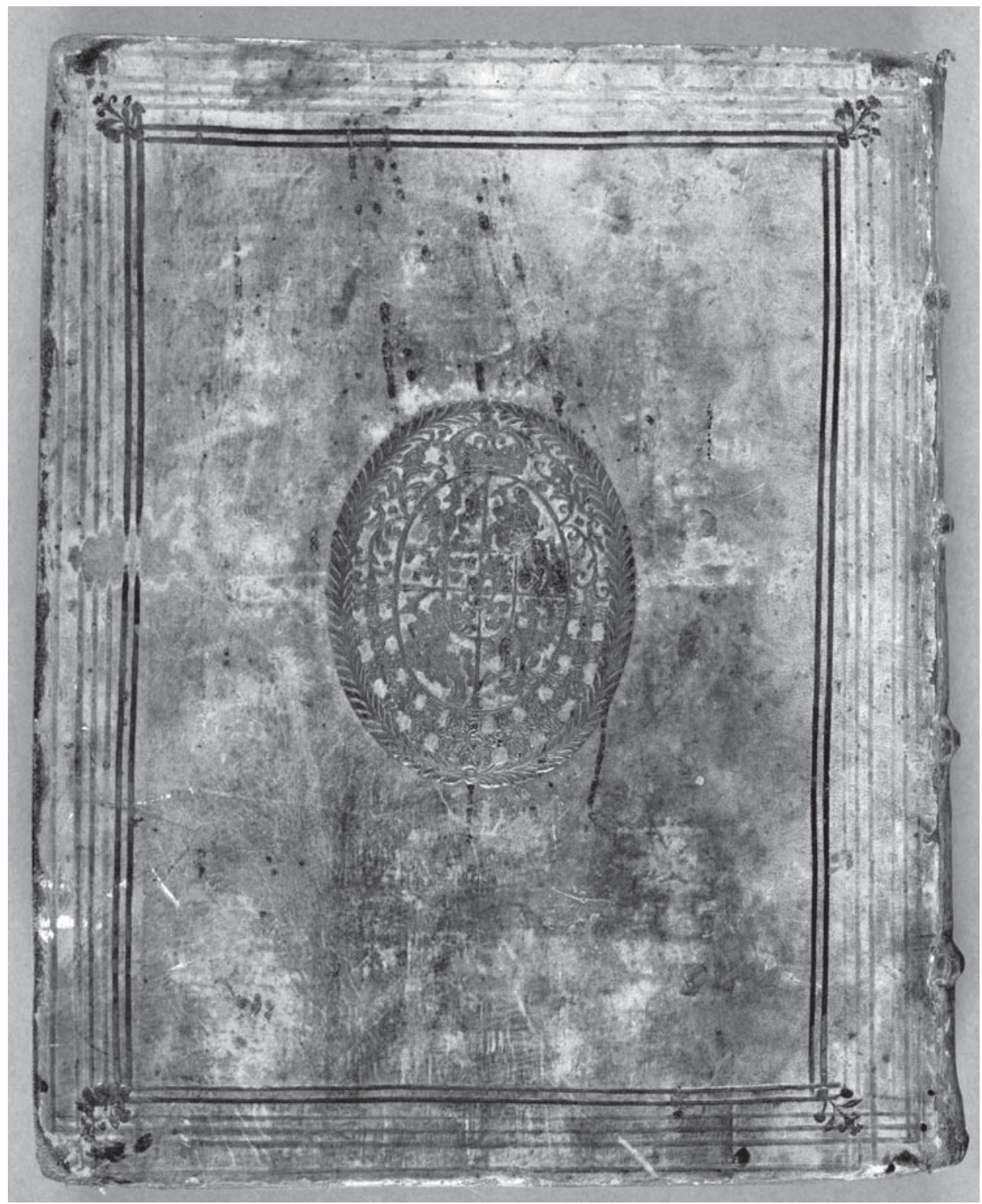

Superekslibrys z herbem Wazów okładziny dolnej książki Vox turturis seu de Florenti usque ad nostra tempora SS. Benedicti, Dominici, Francisci... 


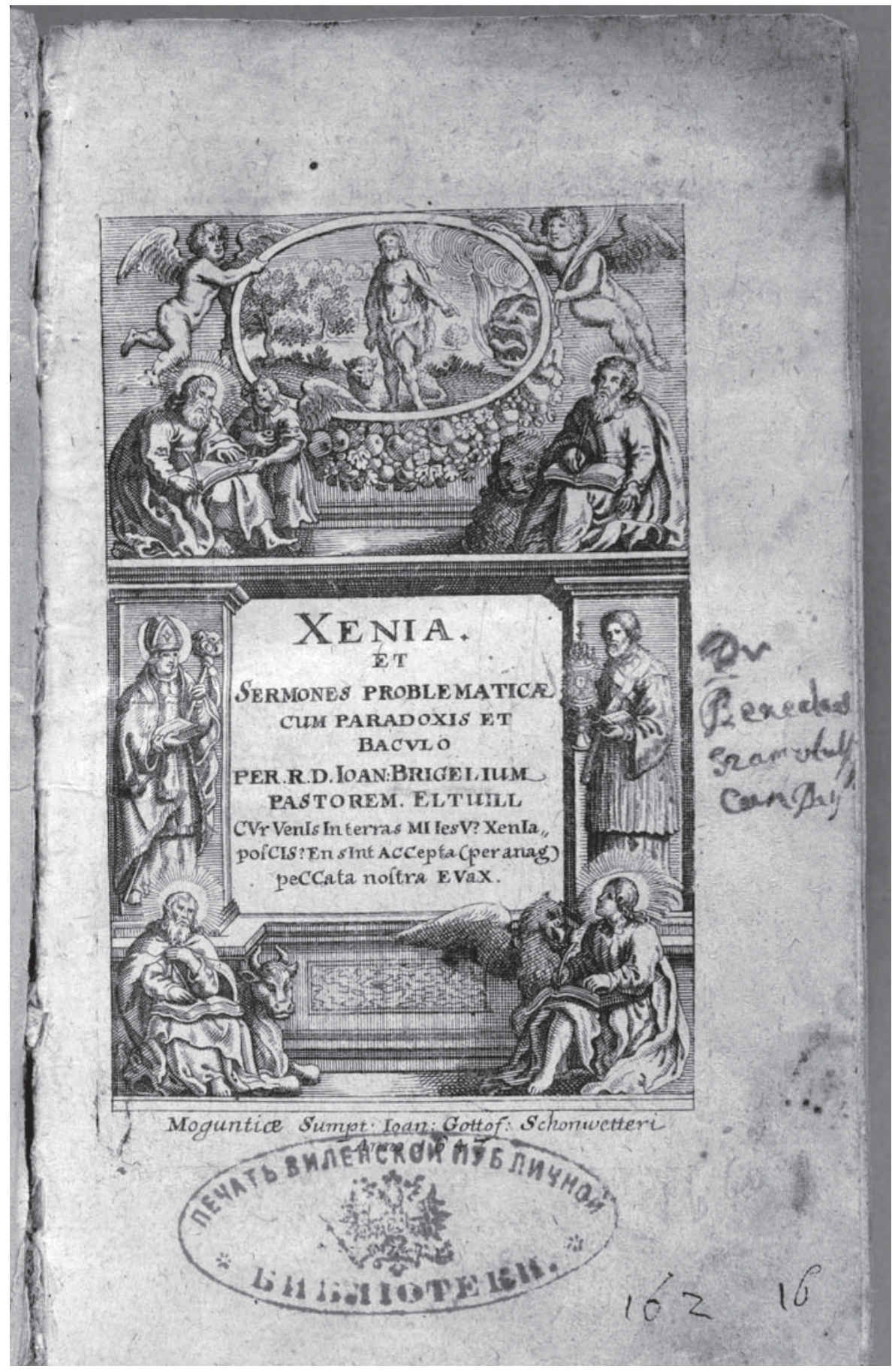

Frontyspis - Xenia et sermones problematicae cum paradoxis et baculo, Moguncja 1647 


\section{VITIS MYSTICA;}

VITI VERÆ, QU Æ CHRISTUS EST,ET PALMITIBUS ejus, hoceft electis à Deo coclitibus quorum fefta per facrum anni circulum occurrunt, prxinferta \& innixa.

\section{$\begin{array}{llllll}H & O & C & E & S & T\end{array}$}

\section{CONCIONES FLORID $\not$,}

SACRA SCRIPTURA OPORTUNIS AVTHORITAtibus, yelutizacemis, SS. Patrum \& Doctornm tam veterum quam recentiorum, nếc nomprophanorum Authorum doctrinis moralibus, veluti botris feu uvisf $x$ cundiffimè refertx \& onnftx.

\section{IN SINGULAS TOTIUS ANNI DOMINICAS ET OCCURRENTIA FESTA}

Copiofo elegantique Ordine diftributa,

A U T H O R E

\section{R.P.CHRISTOPHORO BRAUN,}

(SOCIETATIS JESUI THEOLOGO ET ECCLESIASTE.

Cum duplici indice, argumentorum fcilicet, \& rerummemorabilium.
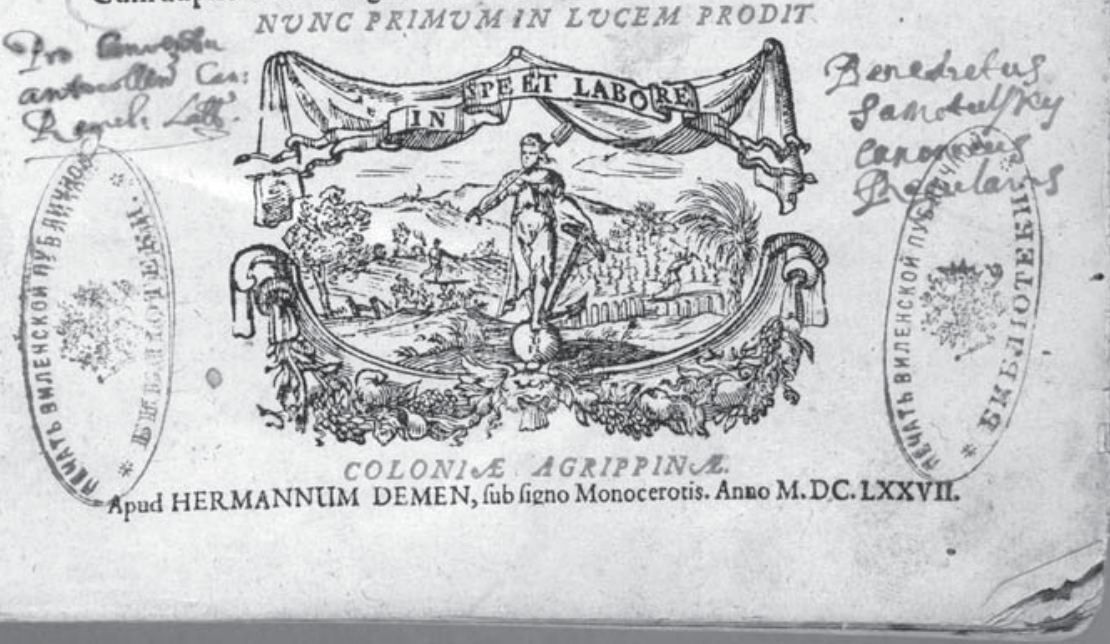

Strona tytułowa - Vitis mystica. Viti verae, quae Christus est..., Kolonia 1677 